\title{
Dilemma in Health during Pandemic in OECD Countries: Increasing Health Expenditures for Preventing against the Pandemic Will Cause a Crowding-out in Increasing the Employment in Nursing Service or not?
}

\author{
Özlem Özsoy ${ }^{1^{*}}$ \\ 1* Ekol Hospital, Izmir, Turkey (ORCID: 0000-0003-4438-5734); ozlem.ozsoy@gmail.com; ozlemozsoy1978@gmail.com
}

(International Conference on Design, Research and Development (RDCONF) 2021 - 15-18 December 2021)

(DOI: $10.31590 /$ ejosat.1051266)

ATIF/REFERENCE: Özsoy, Ö. (2021). Dilemma in Health during Pandemic in OECD Countries: Increasing Health Expenditures for Preventing against the Pandemic Will Cause a Crowding-out in Increasing the Employment in Nursing Service or not?. European Journal of Science and Technology, (32), 1094-1102.

\begin{abstract}
In the early of December 2021, the COVID-19 related cases has exceeded 263 million and deaths 5.2 million. With COVID-19, it has been seen that the health system and health personnel are indispensable in the fight against the virus, even during the pandemic period. For a strong a resilient healthcare system need for nurses has emerged as the COVID-19 spreads very fast. According to WHO 19.3 million of the global nursing workforce which is 27.9 million, and $59 \%$ of the health professions are professional nurses. In OECD countries, there are 13.4 million nurses, and 987 nurses per 100,000 population. While health expenditures are made for treatment and vaccination, it should not be neglected to train health personnel, especially nurses. Increasing health expenditures against pandemic may mostly go to for preventing, vaccines and medical treatment and cause a crowding-out in increasing the employment in nursing service.
\end{abstract}

Keywords: Nurses; Public health, COVID-19, Pandemic, Health expenditure

\section{OECD Ülkelerinde Pandemi Sırasında Sağlıkta İkilem: Salgını Önlemeye Yönelik Sağlık Harcamalarının Artması, Hemşirelik İstihdamını Artırmada Kesintiye Neden Olacak mı Olmayacak mı?}

$\ddot{O} \mathbf{z}$

Aralık 2021'in başlarında, COVID-19 ile ilgili vakalar 263 milyonu ve ölümler de 5,2 milyonu aşmıştır. COVID-19 ile görülmüştür ki, pandemi döneminde bile virüsle mücadelede sağlık sistemi ve sağllk personeli vazgeçilmezdir. Sağllk personeli özellikle hemşireler dünyada eşit olarak dağılmamaktadır. Güçlü ve dayanıklı bir sağlı sistemi için, COVID-19'un çok hızlı yayılmasıyla hemşirelere duyulan ihtiyaç ortaya çıkmıştır. Dünya Sağlık Örgütü'ne göre 27,9 milyon olan küresel iş gücünün 19,3 milyonu ve sağlık personelinin de $\% 59$ 'u profesyonel hemşireler oluşturmaktadır. OECD ülkelerinde 13.4 milyon hemşire mevcut olup, 100.000 nüfusa 987 hemşire düşmektedir. Tedavi ve aşı için sağlık harcamaları yapılırken başta hemşireler olmak üzere sağlık personelinin yetiştirilmesi de ihmal edilmemelidir. Pandemiye karşı artan sağlık harcamaları daha çok korunma, aşı ve tıbbi tedaviye gitmekte ve hemşirelik hizmetlerinde istihdamın artırılmasında bir kesintiye (dışlanmaya) neden olabilmektedir.

Anahtar Kelimeler: Hemşireler, Kamu sağlı̆̆ı, COVID-19, Pandemi, Sağlık harcamaları

*Corresponding Author: ozlem.ozsoy@gmail.com; ozlemozsoy1978@gmail.com 


\section{Introduction}

A novel coronavirus which was emereged at last days of 2019 has fastly spread all over the world and has become not only a global epidemic, but World Health Organization (WHO) has already declared it as a pandemic on March 11, 2020 (Gürler \& Özsoy 2020).

COVID-19 has affected global supply chains and value chains. It has also affected the economies with social and political life in most of the countries negatively. Governments and international organizations have taken strict protective decisions to decrease the effect of the pandemic. Governments and international instituions have tired to support the vulnerable on economies and households (Gürler and Özsoy, 2021). Th pandemic has not only affected the social and economic lives negatively but also disrupted well-being and mental health of the people, as many countries have enchanced the resaerch in science and technology to find medicine and vaccine to fight with the pandemic (Demirbaş and Bozkurt, 2020).

Globally as the first week of December 2021, there were more than 263 million confirmed COVID-19 cases and 5.2 million deaths all over the world (Our World in Data, 2021). With COVID-19, it has been seen that the health system and health personnel are indispensable in the fight against the virus, even during the pandemic period. Increasing demand and need for a strong healthcare workforce including doctors and nurses have been emerged. The lack of equal distribution of health personnel around the world for a resilience health system, which was already a very important problem before the pandemic, has become more evident with the pandemic.

It is seen that The COVID-19 pandemic is not a country's individual problem anymore; it is a global problem even for the human development and a collobarated partnership is needed. Apart from limited capacity of the health system in the countries, skilled health personnel has very crucial importace. Health expenditure which includes not only health consumption expenditures such as salaries, medicine and treatments but investment for infrastructures, equipment and $R \& D$ are very important to fight with the pandemic. Healthworkforce including nurses is teh other main input of the health system in the countries.

Beesides the fail of the limited health system capacity in fighting with pandemic and the negative effect of COVID-19 on work life and economic growth and may cause an increase in the poverty. It seems that, due to the pandemic, one of SDGs of the WHO is to achieve zero hunger and human well-being goals can be disrupted (Özsoy and Gürler, 2022). SDG 3: "Ensure healthy lives and promote well-being for all at all ages" is one of the goals of United Nations (UN) and health expenditure including the all kind of expenditures for the provision of health services, family planning activities, nutrition activities and emergency aid designated for health is a good indicator to achieve this goal (WHO, 2021a). In their report titled "State of the World's Nursing", WHO has stated that health-related SDG targets (SDG $3 \mathrm{c}$ ) and to education (SDG 4), gender (SDG 5), decent work and economic growth (SDG 8) are the SDGs will be contributed by investing in nursing workforce (WHO, 2020).

In fact, as nurses in many parts of the world struggle to access much-needed consumables, including personal protective equipment such as masks, gloves and gowns, in the fight against the pandemic, nursing capacity to provide care has faced with e-ISSN: 2148-2683 great danger due to the increasing workloads, overtime working and risk of being affected by COVID-19 (Jackson et al., 2020).

Many international organizations and countries started to work on stopping the spread of pandemic and decarease the negative effect of virus on human body. After a serial research and developments, different vaccine inventions has come into emerge in some countries. OECD average vaccination rate was $68 \%$ as the first week of December 2021. Portugal, Chile, Iceland, Spain and Korea Republic are the countries which have fully vaccinated more than $80 \%$ of their total population. Colombia and Slovakia Republic are the countries which have fully vaccinated less than $50 \%$ of their total population. Turkey has a $60 \%$ fully vaccination rate which is close but more than USA (Our World in data, 2021).

A skilled health workforce and good working conditions are indispensable to have a strong health system in a country. The healthcare personnel including medical doctors and nurses, are responsible both for daily healthcare needs and emergencies. By 2030, according to the Sustainable Development Goal 3c (SDG $3 \mathrm{c}$ ), mostly in low-income countries and lower-middle income countries, the world needs 18 million more healthcare staff and nine millon of them are the nurses and midwives (WHO, 2021b).

In honour of the 200th anniversary of the birth of Florence Nightingale and in recognition of her contribution to health and humanity, the year 2020 has been designated as the "International Year of the Nurse and the Midwife" by the WHO (2021c). Unfortunately, the pandemic has continued in 2021. For health personnels' unwavering dedication in fighting against the COVID-19 pandemic, the WHO has also dedicated the year 2021 as the International Year of Health and Care Workers with appreciation and gratitude (WHO, 2021d). Besides this, as the impact of the pandemic and the visibility of nurses' contributions have increased the American Nurses Association (ANA) have extended "the Year of the Nurse and Midwife" theme into 2021 with WHO and global colleagues (American Nursing Informatics Association, 2021).

The International Council of Nurses (ICN) also worthly kept the theme of nurses' day as "Nurses: a voice to lead; Nursing the world to health" in 2020, and "Nurses: A Voice to Lead - A vision for future healthcare in 2021 (ICN, 2021).

In this study OECD countries are investigated and benchmarked with the number of nurses, health expenditures and deaths related with COVID-19. The relationship between nurses and healthcare expenditure is also analysed in the study. In average, the COVID-19 related deaths per hundred thousand population in OECD was 168 and the members have 987 nurses per hundred thousand population. Health expenditure per capita was 5,029 dollars and the health expenditure as a percentage of GDP was 13.2 percent in average in OECD countries.

\section{Material and Method}

\subsection{Selection of country set}

The study consists of totally 38 countries which are members of OECD. Thirty one of the countries are advanced countries whereas seven of them developing countries. Seventeen members are in the Euro Area and twenty two of them are members of the European Union. The country set is analysed considering the indicators as:

- Nurses per hundred thousand population, 
- COVID-19 related total deaths per hundred thousand population (as December 32021 ),

- Current health expenditure per capita,

- Current health expenditure as a percentage of GDP (\%),

- Population (65+, as a percentage of total population),

- Computed Tomography scanners per million population.

\subsection{Technical notes about the data}

There was a lack of data for the indicators listed above for some countries for some years. Data apart from COVID-19 related total deaths were collected for 2020 and most recent data. COVID-19 related total deaths were gathered on December 3, 2021 from Our World in Data (2021). Health expenditure data for nursing care facilities and continuing care retirement communities has been found just for USA so that it is excluded in the study. As the data are from different resources and in different units, the natural logarithm of the data were used in the study. The data were collected from Eurostat (2021), OECD (2021), T.C. Sağlık Bakanlığı (2021), the World Bank (2021), WHO (2021e and 2021f).

To estimate and analyse the descriptive statistics of the data, the 22nd version of the Statistical Package for Social Sciences Data (SPSS software, IBM Corp., Armonk, NY, USA 2021a) and 9th version of the EViews software (QMS, Emeryville, California, United States 2021) were used.

There are several statistical methods exist to evaluate whether the data are normally distributed or not. Jarque-Bera test, ShapiroWilks test and Kolmogorov-Smirnov test are common tests which were used to analyse the normality of the data. The Shapiro-Wilk test is the method that is more appropriate to be sued for Normality test for the OECD member set which has less than 50 members (Mishra et al. 2019). Parametric tests are applied for a normally distributed data whereas non-parametric tests for nonnormally distributed data set. The Student's t-tests, one-wayANOVA (analysis of variance) are some common parametric statistics for normally distributed data and the Mann-WhitneyWilcoxon (MWW) test, the Wilcoxon test and Kruskal-Wallis tests are common non-parametric statistics for the data which were not distributed normally ((IBM 2021b; Minitab 2015).

For testing the normality of the data, the hypotheses are as:

$\mathrm{H}_{0}$ : The data set statistically distributed normal

$\mathrm{H}_{1}$ : The data set statistically distributed not normal

If the $p$-value is greater than the predefined significance level, here it is $p=0.05$, we are not able to reject the null hypothesis of normality of the data with $95 \%$ confidence. If the probability is greater than 0.05 it indicates that the data are distributed normal and if the probability is smaller than 0.05 it indicates that the data are not normally distributed.

To find the relationship between "nurse per hundred thousand population" and "health expenditure per capita", "health expenditure as a percentage of Gross Domestic Product (GDP)", "deaths related COVID-19 per hundred thousand population", "population who are 65 and over", "Computed Tomography scanners per million population", the ordinary least squares (OLS) method was applied to estimate the parameters of the regression. Hence the model is as;

$Y_{i}=\beta_{0}+\beta_{1} X_{1 i}+\beta_{2} X_{2 i} \beta_{3} X_{3 i}+\beta_{4} X_{4 i}+\beta_{5} X_{5 i}+\varepsilon_{i}$ where $Y$ is the dependent variable, $X_{1 i}, X_{2 i}, X_{3 i}, X_{4 i}$ and $X_{5 i}$ are the explanatory variables (or regressors), $\beta_{0}$ is the intercept and $\beta_{1,2,3,4,5}$ are coefficients of the explanatory variables (slopes), $\varepsilon$ is the e-ISSN: 2148-2683 stochastic disturbance term for the sample, and $i$ the $i$ th country (Gujarati \& Porter, 2009).

$\mathrm{Y}_{\mathrm{i}}$ : Nurses per hundred thousand population (2020 or more recent year data),

$\mathrm{X}_{1 \mathrm{i}}$ : COVID-19 related total deaths per hundred thousand population as December 32021 ,

$\mathrm{X}_{2 \mathrm{i}}$ : Current health expenditure per capita $(\$, 2020$ or more recent year data),

$\mathrm{X}_{3 \mathrm{i}}$ : Current health expenditure as a percentage of GDP (\$, 2020 or more recent year data),

$\mathrm{X}_{4 \mathrm{i}}$ : Computed Tomography scanners per million population (2020 or more recent year data),

$\mathrm{X}_{5 \mathrm{i}}$ : Population (2020, 65+, \% of total population).

The regression above measures the relationship between nurse personnel $\left(\mathrm{Y}_{\mathrm{i}}\right)$ and COVID-19 related deaths $\left(\mathrm{X}_{1 \mathrm{i}}\right)$ and health expenditure per capita and $\left(\mathrm{X}_{2 \mathrm{i}}\right), \quad\left(\mathrm{X}_{3 \mathrm{i}}\right),\left(\mathrm{X}_{4 \mathrm{i}}\right)$ and $\left(\mathrm{X}_{5 \mathrm{i}}\right)$ are the control variables included in the regression.

\section{Results and Discussion}

\subsection{Results}

In the study the relationship between the "nurse per hundred thousand population", "health expenditure per capita", "health expenditure as a percentage of Gross GDP, "deaths related COVID-19 per hundred thousand population", "population (65+"

and "Computed Tomography scanners per million population" was estimated and investigated by descriptive statistics and OLS regression.

In OECD, nurse per 100,000 population (2020 or more recent year data) is 987 in average; Sweden is top ranked with 1,963 nurses whereas Norway with 1,801 nurses and Switzerland with 1,783 nurses have followed Sweden. Colombia has the lowest score with 138 nurses.

In OECD, health expenditure per capita is 5,029 $\$$ in average; USA is top ranked with 10,907 whereas Switzerland with 9,563 $\$$ and Norway with 7,644 \$ have followed USA. Turkey has the lowest score with 392 \$.

In OECD, health expenditure as a percentage of GDP is $13.17 \%$ in average; USA is top ranked with $17.20 \%$ whereas United Kingdom with 12.51 percent and Germany with 12.38 percent have followed USA. Turkey has the lowest score with $4.59 \%$.

In OECD, deaths related COVID-19 per 100,000 population (as December 3, 2021) is 168.5 in average; Hungary is top ranked with 360.2 whereas Czech Republic (Czechia) with 312.6 deaths and Slovak Republic (Slovakia) with 269.2 deaths have followed Hungary. New Zealand has the lowest score with 0.9 deaths.

In OECD, population who are 65 and above is 17.40 percent in average; Japan is top ranked with 28.40 share whereas Italy with 23.30 percent and Portugal with 22.77 percent have followed Japan. Mexico has the lowest score with 7.62 percent, so that Japan, Italy, Portugal, Finland and Greece government should think more about the public health policies about older population, increasing old-age dependency and decrease in labour force for economic activities. Turkey has the second least old age population share after Mexico in 38 OECD countries.

In OECD, Computed Tomography scanners per million population is $26.7 \mathrm{CT}$ in average; Hungary is top ranked with 111.5 CT whereas Australia with 69.74 CT and Iceland with 46.7 
CT have followed Hungary. Costa Rica has the lowest score with 3.2 CT (Table 1).

Table 1. Health related indicators in OECD countries

\begin{tabular}{|c|c|c|c|c|c|c|}
\hline Country & $\begin{array}{l}\text { Nurse per } \\
100,000 \\
\text { population } \\
\text { (2020 or } \\
\text { more recent } \\
\text { year data) }\end{array}$ & $\begin{array}{c}\text { Health } \\
\text { expenditure } \\
\text { per capita (\$, } \\
2020 \text { or more } \\
\text { recent year } \\
\text { data) }\end{array}$ & 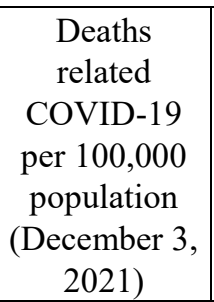 & $\begin{array}{c}\text { Health } \\
\text { expenditure as } \\
\text { a percentage } \\
\text { of GDP }(\%, \\
2020 \text { or more } \\
\text { recent year } \\
\text { data) }\end{array}$ & $\begin{array}{c}\text { Population } \\
\text { ages } 65 \text { and } \\
\text { above ( } 2020, \\
\% \text { of total } \\
\text { population) }\end{array}$ & $\begin{array}{l}\text { Computed } \\
\text { Tomography } \\
\text { (CT) scanners } \\
\text { per million } \\
\text { population }\end{array}$ \\
\hline Australia & 1,206 & 5,058 & 7.9 & 9.78 & 16.21 & 69.74 \\
\hline Austria & 1,033 & 5,523 & 142.3 & 11.37 & 19.20 & 28.72 \\
\hline Belgium & 1,095 & 4,917 & 235.1 & 10.89 & 19.25 & 24.04 \\
\hline Canada & 988 & 4,969 & 78.4 & 11.49 & 18.10 & 14.61 \\
\hline Chile & 1,237 & 1,240 & 201.1 & 9.37 & 12.24 & 24.21 \\
\hline Colombia & 138 & 490 & 252.9 & 9.19 & 9.06 & 5.93 \\
\hline Costa Rica & 335 & 913 & 143.5 & 7.52 & 10.25 & 3.16 \\
\hline Czech Republic & 854 & 2,065 & 312.6 & 9.01 & 20.14 & 16.40 \\
\hline Denmark & 1,003 & 6,469 & 50.4 & 10.59 & 20.16 & 40.59 \\
\hline Estonia & 622 & 1,874 & 136.0 & 8.14 & 20.37 & 18.84 \\
\hline Finland & 1,354 & 4,676 & 24.6 & 9.59 & 22.55 & 16.30 \\
\hline France & 1,072 & 4,773 & 178.7 & 12.23 & 20.75 & 18.17 \\
\hline Germany & 1,392 & 5,721 & 123.7 & 12.38 & 21.69 & 35.33 \\
\hline Greece & 338 & 1,502 & 172.0 & 8.52 & 22.28 & 42.53 \\
\hline Hungary & 664 & 1,065 & 360.2 & 6.66 & 20.16 & 9.40 \\
\hline Iceland & 1,563 & 5,822 & 9.6 & 9.82 & 15.62 & 46.69 \\
\hline Ireland & 1,255 & 6,020 & 114.3 & 7.06 & 14.58 & 20.34 \\
\hline Israel & 493 & 3,196 & 89.0 & 7.24 & 12.41 & 9.72 \\
\hline Italy & 608 & 3,073 & 225.1 & 9.69 & 23.30 & 36.46 \\
\hline Japan & 1,229 & 4,444 & 14.6 & 11.06 & 28.40 & 111.49 \\
\hline Korea, Rep. & 793 & 2,649 & 7.4 & 8.37 & 15.79 & 39.63 \\
\hline Latvia & 442 & 1,178 & 223.4 & 6.65 & 20.69 & 37.10 \\
\hline Lithuania & 774 & 1,511 & 243.5 & 7.47 & 20.62 & 31.14 \\
\hline Luxembourg & 1,106 & 6,039 & 139.2 & 5.21 & 14.39 & 22.26 \\
\hline Mexico & 279 & 518 & 228.7 & 6.22 & 7.62 & 6.44 \\
\hline Netherlands & 1,063 & 5,858 & 114.9 & 11.18 & 20.03 & 14.87 \\
\hline New Zealand & 1,061 & 3,795 & 0.9 & 9.16 & 16.37 & 15.26 \\
\hline Norway & 1,801 & 7,644 & 20.3 & 11.34 & 17.53 & 31.11 \\
\hline Poland & 614 & 1,121 & 224.3 & 7.13 & 18.74 & 18.17 \\
\hline Portugal & 687 & 2,267 & 179.4 & 10.22 & 22.77 & 17.79 \\
\hline Slovak Republic & 569 & 1,479 & 269.2 & 7.68 & 16.70 & 17.78 \\
\hline Slovenia & 1,022 & 2,443 & 251.0 & 9.57 & 20.74 & 19.09 \\
\hline Spain & 586 & 2,687 & 186.2 & 9.93 & 19.98 & 19.20 \\
\hline Sweden & 1,963 & 5,951 & 146.5 & 11.38 & 20.33 & 26.17 \\
\hline Switzerland & 1,783 & 9,563 & 134.2 & 10.98 & 19.10 & 38.72 \\
\hline Turkey & 269 & 392 & 91.8 & 4.59 & 8.98 & 14.69 \\
\hline United Kingdom & 845 & 5,143 & 217.0 & 12.51 & 18.65 & 8.76 \\
\hline United States & 1,557 & 10,907 & 239.1 & 17.20 & 16.63 & 42.43 \\
\hline OECD total & 987 & 5,029 & 168.53 & 13.17 & 17.40 & 26.67 \\
\hline
\end{tabular}

Source: Eurostat (2021), OECD (2021), the World Bank (2021), T.C. Sağlık Bakanlı̆̆ı (2021), WHO (2021e), WHO (2021f) 
Otherwise, "health expenditure per capita", "population ages 65 and above", and "Computed Tomography scanners per million population" data are not normally distributed as their significance level is smaller than 0.05 and we reject null hypothesis which indicates data are normally distributed. Non-parametric tests can be applied to these data which were not distributed normally. By Jarque-Bera test, "Computed Tomography scanners per million population" is not normally distributed as the significance level is smaller than 0.05 and we reject the null hypothesis which indicates data is normally distributed whereas the other data are normally distributed (Hata! Başvuru kaynağı bulunamadı.). we are not able to reject null hypothesis. By Shapiro-Wilk test, "Nurse per hundred thousand population", "deaths related COVID-19 per hundred thousand population", and "health expenditure as a percentage of GDP" data have normal distribution and parametric tests can be applied to these data.

Table 2. Test of Normality (IBM, 2021a), (Eviews, 2021)

\begin{tabular}{|l|c|c|c|c|c|c|c|c|c|}
\hline & \multicolumn{3}{|c|}{ Kolmogorov-Smirnov $^{\mathrm{a}}$} & \multicolumn{3}{c|}{ Shapiro-Wilk } & \multicolumn{3}{c|}{ Jarque-Bera } \\
\cline { 2 - 10 } & Statistic & df & Sig. & Statistic & df & Sig. & Statistic & df & Sig. \\
\hline $\begin{array}{l}\text { Nurse per 100,000 population } \\
\text { (2020 or more recent year } \\
\text { data) }\end{array}$ & .080 & 38 &, $200^{*}$ & .975 & 38 & .557 & 1.026 & 38 & .599 \\
\hline $\begin{array}{l}\text { Health expenditure per capita } \\
\left(\begin{array}{l}\$, 2020 \text { or more recent year } \\
\text { veri) }\end{array}\right.\end{array}$ & .117 & 38 &, $200^{*}$ & .928 & 38 & .018 & 2.925 & 38 & .232 \\
\hline $\begin{array}{l}\text { Deaths related COVID-19 per } \\
\begin{array}{l}\text { 100,000 population } \\
\text { (December 3, 2021) }\end{array}\end{array}$ & .099 & 38 &, $200^{*}$ & .959 & 38 & .181 & .894 & 38 & .640 \\
\hline $\begin{array}{l}\text { Health expenditure as a } \\
\text { percentage of GDP (\%, 2020 } \\
\text { or more recent year veri) }\end{array}$ & .090 & 38 &, $200^{*}$ & .959 & 38 & .178 & 4.865 & 38 & .088 \\
\hline $\begin{array}{l}\text { Population ages 65 and above } \\
\text { (2020, \% of total population) }\end{array}$ & .141 & 38 & .053 & .941 & 38 & .044 & 1.968 & 38 & .374 \\
\hline $\begin{array}{l}\text { Computed Tomography } \\
\text { scanners per million } \\
\text { population }\end{array}$ & .155 & 38 & .022 & .784 & 38 & .000 & 121.157 & 38 & .000 \\
\hline
\end{tabular}

In Table 3 the results of the ordinary least squares (OLS) method can be seen. It is obviously clear that "nurse per hundred thousand population" is positively correlated with "health expenditure per capita" and negatively correlated with "COVID19 related total deaths per hundred thousand population" but the model is not significant so that the correlation between "nurse per hundred thousand population" and "health expenditure per capita" and negatively correlated with "COVID-19 related total deaths per hundred thousand population" should be investigated partially.

Table 3. Statistical output of the regression between nurses and health related explanatory variables (Eviews, 2021)

\begin{tabular}{|c|c|c|c|c|}
\hline $\begin{array}{l}\text { Dependent Variable: Nurse per } 100,000 \text { population ( } 2020 \text { or more recent } \\
\text { year data, natural logarithm) }\end{array}$ & & Included observations: 3 & & \\
\hline Variable & Coefficient & Std. Error & $\begin{array}{c}\mathrm{t}- \\
\text { Statistic }\end{array}$ & Prob. \\
\hline $\mathrm{C}$ & 1.95 & 0.65 & 3.02 & 0.00 \\
\hline $\begin{array}{l}\text { COVID-19 related total deaths per hundred thousand population (natural } \\
\text { logarithm) }\end{array}$ & -0.02 & 0.04 & -0.41 & 0.68 \\
\hline Health expenditure per capita (natural logarithm) & 0.54 & 0.09 & 5.79 & 0.00 \\
\hline Current health expenditure as a percentage of GDP (natural logarithm) & -0.09 & 0.27 & -0.33 & 0.75 \\
\hline Computed Tomography scanners per million population (natural logarithm) & 0.10 & 0.10 & 1.00 & 0.32 \\
\hline Population $(65+, \%$ of total population (natural logarithm) & 0.15 & 0.25 & 0.61 & 0.55 \\
\hline R-squared & 0.76 & Mean dependent var & 6.70 & \\
\hline Adjusted R-squared & 0.72 & S.D. dependent var & 0.59 & \\
\hline S.E. of regression & 0.31 & Akaike info criterion & 0.64 & \\
\hline Sum squared resid & 3.08 & Schwarz criterion & 0.90 & \\
\hline Log likelihood & -6.19 & Hannan-Quinn criter. & 0.73 & \\
\hline F-statistic & 20.49 & Durbin-Watson stat & 2.57 & \\
\hline Prob(F-statistic) & 0.00 & & & \\
\hline
\end{tabular}




\section{Nurses and health expenditure}

Graph of the relationship between that "nurse per hundred thousand population" and "health expenditure per capita" shows that there is a positive correlation between the indicators (

Figure 1).

Figure 1. Graph of the relationship between nurses and health expenditure per capita (IBM, 2021a)

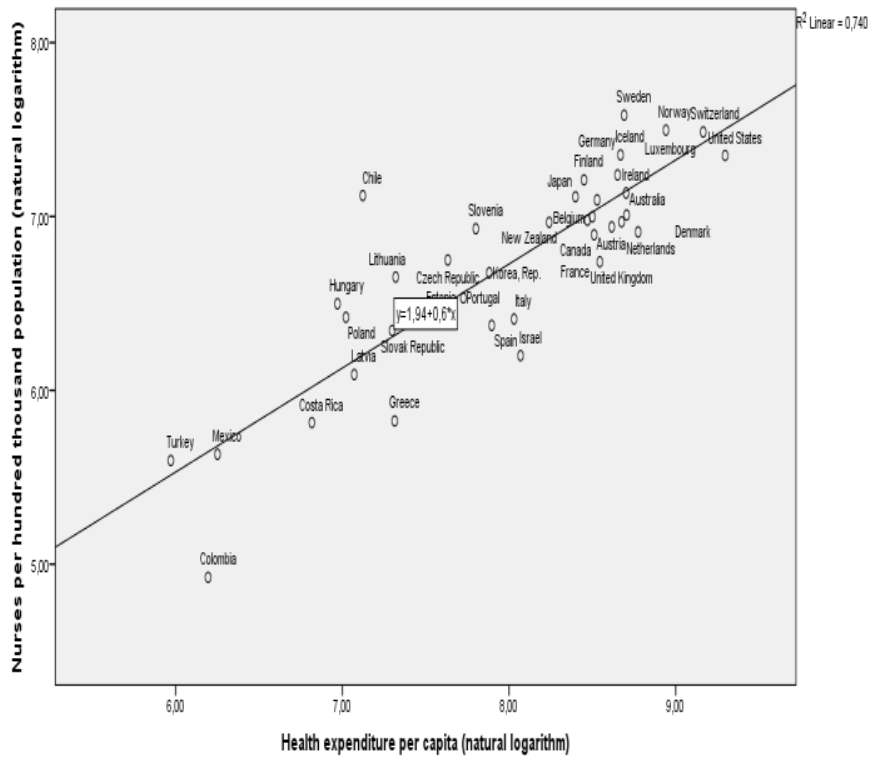

\begin{tabular}{|c|c|c|c|c|}
\hline $\begin{array}{l}\text { Dep. Var: } \\
\text { Nurses per } \\
100,000 \text { pop. } \\
\text { (nat. log.) }\end{array}$ & & Included observa & ions: 38 & \\
\hline Variable & Coefficient & Std. Error & $\begin{array}{c}\mathrm{t}- \\
\text { Statistic }\end{array}$ & Prob. \\
\hline $\mathrm{C}$ & 1.94 & 0.47 & 4.10 & 0.00 \\
\hline $\begin{array}{l}\text { Health } \\
\text { expenditure } \\
\text { per capita } \\
\text { (nat. log.) }\end{array}$ & 0.60 & 0.06 & 10.12 & 0.00 \\
\hline R-squared & 0.74 & $\begin{array}{l}\text { Mean dependent } \\
\text { var }\end{array}$ & \multicolumn{2}{|l|}{6.70} \\
\hline $\begin{array}{l}\text { Adjusted } \\
\text { R-squared }\end{array}$ & 0.73 & $\begin{array}{l}\text { S.D. dependent } \\
\text { var }\end{array}$ & \multicolumn{2}{|l|}{0.59} \\
\hline $\begin{array}{l}\text { S.E. of } \\
\text { regression }\end{array}$ & 0.31 & $\begin{array}{l}\text { Akaike info } \\
\text { criterion }\end{array}$ & \multicolumn{2}{|l|}{0.52} \\
\hline $\begin{array}{l}\text { Sum squared } \\
\text { resid }\end{array}$ & 3.37 & $\begin{array}{l}\text { Schwarz } \\
\text { criterion }\end{array}$ & \multicolumn{2}{|l|}{0.61} \\
\hline Log likelihood & -7.87 & $\begin{array}{l}\text { Hannan-Quinn } \\
\text { criter. }\end{array}$ & \multicolumn{2}{|l|}{0.55} \\
\hline F-statistic & 102.48 & $\begin{array}{l}\text { Durbin-Watson } \\
\text { stat }\end{array}$ & \multirow{2}{*}{\multicolumn{2}{|c|}{2.56}} \\
\hline Prob(F-statistic) & 0.00 & & & \\
\hline
\end{tabular}

If the relationship between "nurse per hundred thousand population" and "health expenditure per capita" is wanted to be analysed by regression the results will be as below. About seventy four percent of the changes in "nurse per hundred thousand population" was explained by the regression (

Table 4).

Table 4. Statistical output of the regression between nurses and health expenditure per capita (Eviews, 2021)

\section{Nurses and older population}

Graph of the relationship between "nurse per hundred thousand population" and "population ages 65 and above as a percentage of total population" shows that there is a positive correlation between the indicators (Figure 2).

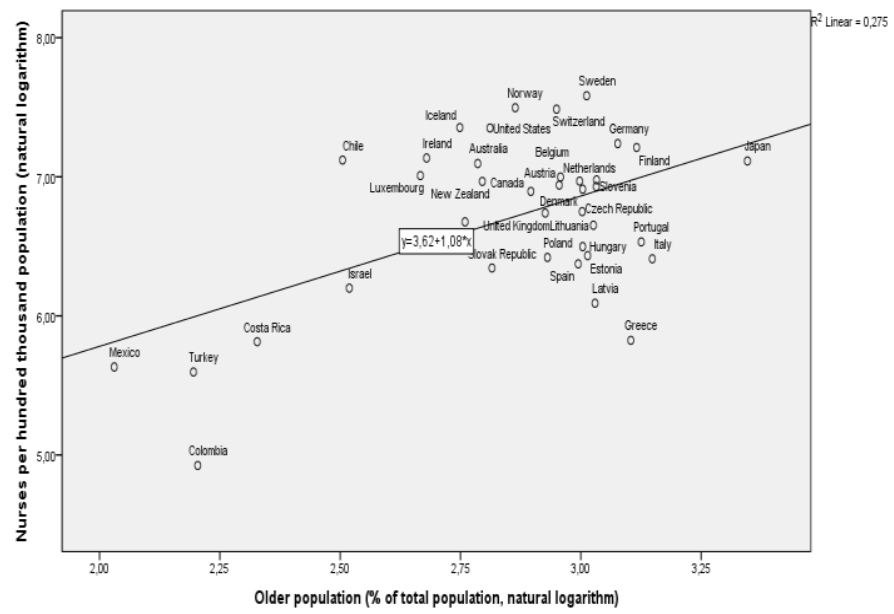

Figure 2. Graph of the relationship between nurses and older population (65 and above, \% of total population) (IBM, 2021a)

If the relationship between "nurse per hundred thousand population" and "population ages 65 and above as a percentage of total population" is wanted to be analysed by regression the results will be as below. About twenty eight percent of the changes in "nurse per hundred thousand population" was explained by the regression. As the older population share in the country increases the need for nurses to care the older population increase (Table 5).

Table 5. Statistical output of the regression between nurses and older population (65\%, \% of total population) (Eviews, 2021)

\begin{tabular}{|l|c|c|c|c|}
\hline $\begin{array}{l}\text { Dep. Var: Nurses } \\
\text { per } 100,000 \text { pop. } \\
\text { (nat. log.) }\end{array}$ & \multicolumn{4}{|c|}{} \\
\hline Variable & $\begin{array}{l}\text { Coeffici } \\
\text { ent }\end{array}$ & Std. Error & $\begin{array}{c}\text { Statisti } \\
\text { c }\end{array}$ & $\begin{array}{c}\text { Pro } \\
\text { b. }\end{array}$ \\
\hline C & 3.62 & 0.84 & 4.32 & 0.00 \\
\hline $\begin{array}{l}\text { Population } \\
(65+\%)\end{array}$ & 1.08 & 0.29 & 3.70 & 0.00 \\
\hline
\end{tabular}




\begin{tabular}{|l|c|l|c|}
\cline { 3 - 4 } & & $\begin{array}{l}\text { Mean } \\
\text { R-squared }\end{array}$ & 0.28 \\
\hline $\begin{array}{l}\text { Adjusted R- } \\
\text { squared }\end{array}$ & 0.26 & $\begin{array}{l}\text { S.D. dependent } \\
\text { var }\end{array}$ & 6.70 \\
\hline S.E. of regression & 0.51 & $\begin{array}{l}\text { Akaike info } \\
\text { criterion }\end{array}$ & 0.59 \\
\hline Sum squared resid & 9.38 & $\begin{array}{l}\text { Schwarz } \\
\text { criterion }\end{array}$ & 1.54 \\
\hline Log likelihood & -27.34 & $\begin{array}{l}\text { Hannan-Quinn } \\
\text { criter. }\end{array}$ & 1.63 \\
\hline F-statistic & 13.68 & $\begin{array}{l}\text { Durbin-Watson } \\
\text { stat }\end{array}$ & 1.58 \\
\hline $\begin{array}{l}\text { Prob } \\
\text { (F-statistic }\end{array}$ & 0.00 & & 1.91 \\
\hline
\end{tabular}

\begin{tabular}{|l|c|l|c|}
\cline { 3 - 3 } Adjusted R-squared & 0,08 & $\begin{array}{l}\text { S.D. } \\
\text { dependent } \\
\text { var }\end{array}$ & 1,31 \\
\hline S.E. of regression & 1,26 & $\begin{array}{l}\text { Akaike } \\
\text { info } \\
\text { criterion }\end{array}$ & 3,35 \\
\hline Sum squared resid & 57,09 & $\begin{array}{l}\text { Schwarz } \\
\text { criterion }\end{array}$ & 3,44 \\
\hline Log likelihood & $-61,65$ & $\begin{array}{l}\text { Hannan- } \\
\text { Quinn } \\
\text { criter. }\end{array}$ & 3,38 \\
\hline F-statistic & & $\begin{array}{l}\text { Durbin- } \\
\text { Watson } \\
\text { stat }\end{array}$ & \\
\hline Prob(F-statistic) & 0,05 & & 1,80 \\
\hline
\end{tabular}

\section{Nurses and COVID-19 related deaths}

Graph of the relationship between that "COVID-19 related total deaths per hundred thousand population" and "nurse per hundred thousand population" shows that there is a negative correlation between two indicators (Figure 3).

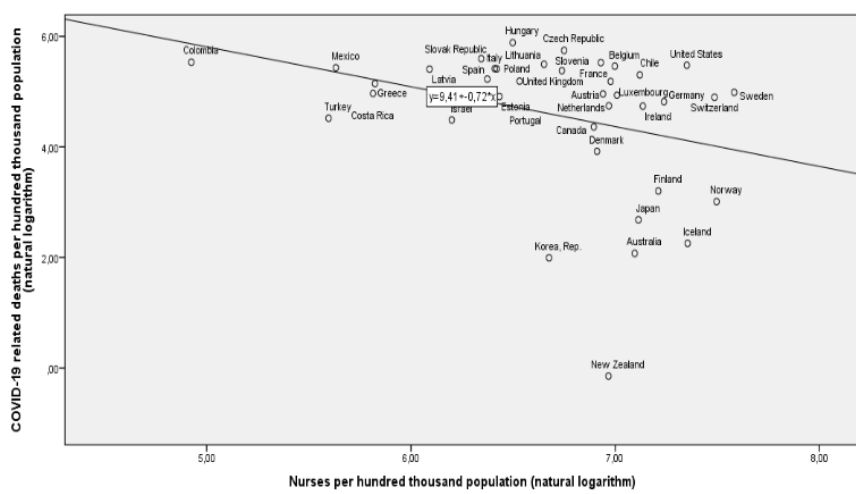

Figure 3. Graph of the relationship between nurses and COVID19 related deaths (IBM, 2021a)

If the relationship between "COVID-19 related total deaths per hundred thousand population" and "nurse per hundred thousand population" above is wanted to be analysed by regression the results will be as below. About eleven percent of the changes in "COVID-19 related total deaths per hundred thousand population" was explained by the regression. As the number of the nurses in the population increases COVID-19 related total deaths decreases and vice versa (Table 6).

Table 6. Statistical output of the regression between COVID-19 related deaths and nurses (Eviews, 2021)

\begin{tabular}{|l|c|c|c|c|}
\hline $\begin{array}{l}\text { Dep. Var.: } \\
\text { COVID-19 related } \\
\text { total deaths }\end{array}$ & & \multicolumn{3}{|c|}{} \\
\hline Variable & $\begin{array}{l}\text { Coeffi } \\
\text { cient }\end{array}$ & Std. Error & $\begin{array}{c}\text { Statistic } \\
\text { C }\end{array}$ & Prob. \\
\hline $\begin{array}{l}\text { Nurses per 100,000 } \\
\text { pop.(nat. log.) }\end{array}$ & 9,41 & 2,35 & 4,00 & 0,00 \\
\hline R-squared & $-0,72$ & 0,35 & $-2,06$ & 0,05 \\
\hline
\end{tabular}

\subsection{Discussion}

Health personnel such as nurses play crucial role for fighting with a pandemic in the health system besides the hospitals, the medical technology. Nurses are important either to prevent the diseases and to treatment or to care older population in a country. As a result, while making investments in health in a country, training of exist nurses and graduation of new nurses are important as other infrastructure, devices and medicines. Otherwise increasing health expenditures against pandemic may mostly go to for preventing, vaccines and medical treatment and cause a crowdingout in increasing the employment in nursing service.

In the study, it is found that the number of nurses and health expenditure are positive correlated. In his study, Atalan (2021) has found that the health expenditure has a positive effective on the number of nurses based on the regression analysis.

Turkey is ranked as 37 th country with 2.69 nurses per thousand population for 2020 (T.C. Sağlık Bakanlığı, 2021). In their study, Pinar and Sert (2009) have found that Turkey was in the last place in terms of nurses per thousand people among 51 countries in the European region of WHO. They have also declared that it is not possible to meet the health care needs of the older people in Turkey with these nurse statistics. For this reason, intermediate health personnel should urgently be trained to meet the needs in elderly care.

In U.S. total health expenditure has reached \$4.1 trillion or 12,530 dollars per person increasing 9.7 percent in 2020 comparing with 2019. Health expenditures accounted for 19.7 percent and it makes U.S. the top ranked country which has the highest value and share of the nation's Gross Domestic Product. In USA, the share for nursing care facilities and continuing care retirement communities is nearly 4.77 percent of national health expenditures, 5.01 percent of health consumption expenditures and 5.86 percent of personal health care and all the shares have been increasing year by year (U.S. Centers for Medicare \& Medicaid Services, 2021).

Especially in high income countries, the improvements in healthinnovations and increasing health expenditure ends up with a longer life expectancy at birth. The social states should provide public health and health care for all their citizens but more for older ones. Otherwise older people may face with lower physical and mental capacity and this will affect them negatively in their additional living years (Özsoy \& Gürler, 2021). 


\section{Conclusion}

The highlights which were obtained from the study are as below:

- In OECD, nurse per 100,000 population (2020 or more recent year data) is 987 in average; Sweden is top ranked with 1,963 nurses and Colombia has the lowest score with 138 nurses.

- In OECD, health expenditure per capita (\$, 2020 or more recent year data) is 5,029 \$ in average; USA is top ranked with 10,907 \$ and Turkey has the lowest score with 392 $\$$.

- In OECD, health expenditure as a percentage of GDP $(\%, 2020$ or more recent year data) is $13.17 \%$ in average; USA is top ranked with $17.20 \%$ and Turkey has the lowest score with $4.59 \%$.

- In OECD, deaths related COVID-19 per 100,000 population (December 3, 2021) is 168.5 in average; Hungary is top ranked with 360.2 and New Zealand has the lowest score with 0.9 deaths.

- In OECD, population ages 65 and above (2020, \% of total population) is 17.40 percent in average; Japan is top ranked with 28.40 share and Mexico has the lowest score with 7.62 percent, it seems that Japan government should think more about the public health policies about older population and decrease in labour force for economic activities.

- In OECD, Computed Tomography scanners per million population is $26.7 \mathrm{CT}$ in average; Hungary is top ranked with 111.5 CT and Costa Rica has the lowest score with 3.2 CT.

- Nurse per 100,000 population (2020 or more recent year data, natural logarithm) has a positive relationship with the population ages 65 and above (\% of total population, natural logarithm); as the number of the population ages 65 and above increases number of nurses to take care this vulnerable population part increases.

- "Nurse per 100,000 population (2020 or more recent year data, natural logarithm") has a negative relationship with "COVID-19 related total deaths per hundred thousand population (natural logarithm)"; as the number of nurses increases deaths from pandemic decreases.

- "Nurse per 100,000 population (2020 or more recent year data, natural logarithm)" has a positive relationship with the "health expenditure per capita (natural logarithm"); as the health expenditure per capita increases number of nurses increases, so that increasing health expenditure, which will be made for treatment and vaccination, should not be neglected to train health personnel, especially nurses. Increasing health expenditures against pandemic may mostly go to for preventing, vaccines and medical treatment and cause a crowding-out in increasing the employment in nursing service.

- About seventy four percent of the changes in "nurse per hundred thousand population" was explained by "health expenditure per capita".

- About twenty eight percent of the changes in "nurse per hundred thousand population" was explained by the "population ages 65 and above as a percentage of total population". As the older population share in the country increases the need for nurses to care the older population increase.
- About eleven percent of the changes in "COVID-19 related total deaths per hundred thousand population" was explained by "nurse per hundred thousand population". As the number of the nurses in the population increases COVID-19 related total deaths decreases and vice versa.

\section{References}

American Nursing Informatics Association (ANIA). 2021: Year of the Nurse Continues. https://www.ania.org/article/year-ofnurse-2021 (Access: December 15, 2021)

Atalan, A. (2021). Effect of Healthcare Expenditure On The Correlation Between The Number of Nurses and Doctors Employed. International Journal of Health Management and Tourism.

10.31201/ijhmt.949500. https://dergipark.org.tr/en/download/article-file/1898476 (Access: December 19, 2021)

Demirbaş D \& Bozkurt V (2020). Introduction. In Demirbaş D (Editor), Bozkurt V (Editor), Yorğun S (Editor) (Eds), The Covid-19 Pandemic And Its Economic, Social, And Political Impacts (p. Vii).İstanbul: İstanbul University Press. 10.26650/B/SS46.2020.006

https://iupress.istanbul.edu.tr/en/book/the-covid-19pandemic-and-its-economic-social-and-politicalimpacts/home (Access: December 15, 2021)

Eurostat (2021). Health statistics. https://ec.europa.eu/eurostat/web/health/overview (Access: December 20, 2021)

EViews. 2021. Innovative Solutions for econometric analysis, forecasting \& simulation. https://www.eviews.com/home.html (Access: December 19, 2021)

Gujarati, D. N. \& Porter, D.C. (2009), Basic Econometrics. McGraw-Hill/Irwin, 5th edition, p. 98.\& p.888. https://cbpbu.ac.in/userfiles/file/2020/STUDY_MAT/ECO/1 .pdf (Access: 19 December, 2021)

Gürler M, Özsoy Ö. (2020). Benchmarking the Devastating Effects of COVID-19 on Economies and Social Life in the EU and In Selected Countries Mostly Affected By the Pandemic. Diversity and Equality in Health and Care (2020) 17(4): $\quad$ 136-145. DOI:10.36648/2049-5471.17.4.204 https://diversityhealthcare.imedpub.com/benchmarking-thedevastatng-eects-of-covid19-on-economies-and-social-lifein-the-eu-and-in-selected-countries-mostly-aected-bythe.pdf (Access: December 21, 2021)

Gürler M, Özsoy Ö. (2021). The Health System Infrastructure and Economic Effects of COVID-19 in OECD Countries, the Policy Responses of Nations and international Organizations against Pandemic. Diversity and Equality in Health and Care (2021) 18(4): 258-275. https://diversityhealthcare.imedpub.com/the-health-systeminfrastructure-and-economic-effects-of-covid19-in-oecdcountries-the-policy-responses-of-nations-andinternation.pdf (Access: December 19, 2021)

IBM. 2021a. IBM SPSS Statistics. https:/www.ibm.com/products/spss-statistics (Access: December 19, 2021)

IBM. 2021b. IBM Db2 Warehouse on Cloud/Statistics-parametric and nonparametric. https://www.ibm.com/docs/vi/db2woc?topic=proceduresstatistics-parametric-nonparametric (Access: December 19, 2021) 
International Council of Nurses (INC) (2021). International Nurses Day. https://www.icn.ch/what-wedo/campaigns/international-nurses-day (Access: December 15, 2021)

Jackson, D., Bradbury-Jones, C., Baptiste, D., Gelling, L., Morin, K., Neville, S., \& Smith, G. D. (2020). Life in the pandemic: Some reflections on nursing in the context of COVID-19. Journal of clinical nursing, 29(13-14), 2041-2043. https://doi.org/10.1111/jocn.15257

https://www.ncbi.nlm.nih.gov/pmc/articles/PMC7228254/ (Access: December 15, 2021)

Minitab. 2015. Choosing Between a Nonparametric Test and a Parametric Test. https://blog.minitab.com/en/adventures-instatistics-2/choosing-between-a-nonparametric-test-and-aparametric-test (Access: December 19, 2021)

Mishra, P., C. M. Pandey, U. Singh, A. Gupta, C. Sahu, and A. Keshri. 2019. Descriptive statistics and normality tests for statistical data. Annals of cardiac anaesthesia. 22/1: 67-72. https://doi.org/10.4103/aca.ACA_157_18 (Access: December 19, 2021)

Organisation for Economic Co-operation and Development (OECD) (2021). https://stats.oecd.org/ (Access: 20 December, 2021)

Our World in Data (2021). Dataset. https://covid.ourworldindata.org/data/owid-covid-data.csv (Access: December 4, 2021)

Özsoy, Ö. and Gürler, M. (2021) Poverty and social exclusion of older people in ageing European Union and Turkey. J Public Health (Berl.). https://doi.org/10.1007/s10389-021-01525-x (Access: 20 December, 2021)

Özsoy, Ö. \& Gürler, M. (2022). The Negative Effects of COVID19 on the Sustainable Development Goals, Economic Growth, Foreign Trade, and Social Life. In K. Kahime, M. Zahir, M. Hadach, M. El Hidan, \& B. Bougadir (Ed.), Public Health and Economic Resiliency in the Post-COVID-19 Era (pp. 105-155). IGI Global. http://doi:10.4018/978-1-79988202-2.ch007

Pınar, R. \& Sert, H. (2009). Türkiye'nin Ulusal Bakım Politikasi Nasıl Olmalıdır?. Hemşirelikte Araştırma Geliştirme Dergisi, $11 \quad$ (2) 46-55

https://dergipark.org.tr/tr/pub/hemarge/issue/52704/695059 (Access: December 20, 2201)

T.C. Sağlık Bakanlığı, Sağlık Bilgi Sistemleri Genel Müdürlüğü (2021). Sağlık İstatistikleri Y1llı̆̆1 2020 Haber Bülteni. https://sbsgm.saglik.gov.tr/Eklenti/41611/0/haber-bulteni2020pdf.pdf (Access: December 20, 2021)

The World Bank. Data. https://data.worldbank.org/ (Access: December 20, 2201)

U.S. Centers for Medicare \& Medicaid Services (CMS) (2021). National Health Expenditure Data. https://www.cms.gov/files/zip/national-health-expenditurestype-service-and-source-funds-cy-1960-2020.zip (Access: 20 December, 2021)

WHO (2020). State of the world's nursing 2020: investing in education, jobs and leadership. https://apps.who.int/iris/rest/bitstreams/1274201/retrieve (Access: December 15, 2021)

WHO (2021a). NUTRITION LANDSCAPE INFORMATION SYSTEM (NLIS)/Nutrition and nutrition-related health and development data/Health expenditure. https://www.who.int/data/nutrition/nlis/info/healthexpenditure (Access: December 15, 2021)
WHO (2021b). The Global Health Observatory Data: Health workforce: Medical doctors. https:/www.who.int/data/gho/data/themes/topics/indicatorgroups/indicator-group-details/GHO/medical-doctors (Access: December 21, 2021)

WHO (2021c). Home/ Campaigns/ Annual theme/ Year of the Nurse and the Midwife 2020. https://www.who.int/campaigns/annual-theme/year-of-thenurse-and-the-midwife2020\#: :text=The\%20world\%20needs\%209\%20million, the $\% 20$ Nurse $\% 20$ and\%20the\%20Midwife. (Access: December 14, 2021)

WHO (2021d). Home/ Campaigns/ Annual theme/ Year of Health and Care Workers 2021. https://www.who.int/campaigns/annual-theme/year-ofhealth-and-care-workers-2021 (Access: December 14, 2021)

WHO (2021e). The Global Health Observatory. Data. https:/www.who.int/data/gho/data/indicators (Access: December 20, 2021)

WHO (2021f). European Health Information Gateway/Total health expenditure as $\%$ of GDP. https:/gateway.euro.who.int/en/indicators/hfa_566-6711total-health-expenditure-as-of-gdp/ (Access: December 20, 2021) 